\title{
Prevalence and Sensitivity of Bacterial Urinary Tract Infection among Adult Diabetic Patients in Misan Province, Iraq
}

\author{
Nooralden Abdulkarem Jasim Al-Tulaibawi \\ Department of Clinical Laboratories Sciences, College of Pharmacy, University of Misan, Misan, Iraq.
}

\begin{abstract}
Urinary tract infections and their complications causing serious health problems especially in diabetic patients in Misan province, it is essential to determine the causative agent for appropriate treatment of this disease. One hundred and fifty urine samples were taken from adult patients with diabetes. The microbial growth appeared in 106 (70.6\%) samples. Axenic culture was $83 \%$ versus $17 \%$ mixed growth. UTI prevalence was $65 \%$ with females comparing $35 \%$ of males and it was $56.6 \%$ in age group $35-49$ years. Furthermore, UTIs were more incident in patients without antibiotics use and diabetic period $5-10$ years ( $82 \%$ and $64 \%$ ) respectively. Escherichia coli was identified as the most common causative agent of UTIs (52.9\%), followed by Klebsiella pneumoniae and Enterococcus faecalis $(9,1 \%$ and $6.6 \%$, respectively). Streptococcus agalactiae and Klebsiella aerugenes were (4.2\%, for each). Moreover, Pseudomonas aeruginosa, Klebsiella oxytoca and Staphylococcus haemolyticus were $\mathbf{2 . 4 8 \%}$ for each. Additionally, the frequency of Proteus mirablis, Staphylococcus aureus, Streptococcus pyogenes, Serratia marcessens, Staphylococcus epidermidis and Staphylococcus warnerii was $1.65 \%$ for each, while Acinetobacter baumani and Bacillus subtilis were $\mathbf{0 . 8 2} \%$ for each. Most bacterial isolates had a high sensitivity to imipenem (78.8\%) followed by amikacin (61.9\%), but low sensitivity to ceftriaxone, tetracycline and Co-trimaxazole $(36.4 \%, 29.7 \%$ and $26.3 \%$, respectively) whereas, highly resistance to ampiclox and nitrofurantoin (98.3\% and $87.3 \%$, respectively). High rate of multidrug resistance observed among bacterial isolates.
\end{abstract}

Keywords: UTIs; diabetes; bacteria; antibiotic susceptibility; imipenem.

*Correspondence: nooraldeen_bio85@yahoo.com; +9647705531145

(Received: 02 March 2019; accepted: 08 April 2019)

Citation: Nooralden Abdulkarem Jasim Al-Tulaibawi, Prevalence and Sensitivity of Bacterial Urinary Tract Infection among Adult Diabetic Patients in Misan Province, Iraq, J Pure Appl Microbiol., 2019; 13(2): 847- 853. doi: 10.22207/JPAM.13.2.20

(c) The Author(s) 2019. Open Access. This article is distributed under the terms of the Creative Commons Attribution 4.0 International License which permits unrestricted use, sharing, distribution, and reproduction in any medium, provided you give appropriate credit to the original author(s) and the source, provide a link to the Creative Commons license, and indicate if changes were made. 


\section{INTRODUCTION}

Urinary tract infections (UTIs) are one of the most common infectious diseases encountered in medical practice affecting humans of all ages ${ }^{1}$. Globally, UTIs incidence was estimated about 150 million persons per year².

Diabetes mellitus is a group of chronic metabolic disorders characterized by increased blood glucose level resulting from defects in secretion, action of insulin or both ${ }^{3}$. The chronic hyperglycemia is associated with long term damage, dysfunction and failure of different organs especially the eyes, urinary system, nerves and cardiovascular system ${ }^{3}$. Over time, diabetic patients may develop cystopathy, nephropathy and renal papillary necrosis complications that predispose them to UTIs ${ }^{4}$. Higher severity of UTI can be cause many complications, ranging from dysuria to pyelonephritis ${ }^{5}$. Moreover, diabetic patients encounter further urinary urgency and incontinence during night ${ }^{6}$. Further more, those patients frequently suffer from bacterial cystitis with higher prevalence in diabetic women including higher prevalence of both asymptomatic bacteriuria and symptomatic UTI added to recurrent complications comparing with healthy women ${ }^{7,8}$.

In diabetic and non- diabetic patients, about $80 \%$ of UTIs cases were caused by gramnegative bacteria mainly Escherichia coli, Klebsiella spp., Pseudomonas aeruginosa and Proteus spp., while only $15 \%$ were caused by gram-positive including Enterococcus spp., Staphylococcus spp. and Streptococcus spp. ${ }^{9-11}$.

Susceptibility to antibiotics is usually variable among species and strains, therefore, the resistance to different antibiotics making it difficult to treat in some infections ${ }^{12}$. The widespread and indiscriminate use of broad-spectrum antibiotics led to the emergence of multi-drug resistant bacteria ${ }^{13}$.

Briefly, this study was designed to determine the prevalence of causative microbial agents of urinary tract infections in diabetic adult patients and their susceptibility to antibiotics.

\section{PATIENTS AND METHODS Study design}

A descriptive study was conducted at the Microbiology Laboratory, Department of Clinical
Laboratories Sciences, College of Pharmacy, University of Misan, Misan city, South of Iraq over the period from May to August in 2018. This study was approved by Ethical Committees of College of Pharmacy of Misan University with written consent withdrawn from all the patients.

\section{Sample collection}

One hundred and fifty midstream urine samples were obtained from 150 diabetic adult outpatients between 20-64 years old attending to the Microbiological Examinations Unit at Al-Sadar Teaching Hospital in Misan city with written consent. The urine samples were collected by sterilized disposable containers (BIOZEK, Netherlands) after necessary precaution ${ }^{14}$. Samples were brought to the laboratory within one hour. Questionnaires had completed covering the information pertaining to sex, age, period of diabetes and antibiotics used.

\section{Urine culture}

A $0.1 \mathrm{ml}$ of urine sample was inoculated separately onto Blood agar ( $L A B, U K$ ) and MacConkey agar (LAB, UK) plates, and incubated aerobically at $37^{\circ} \mathrm{C}$ for $24 \mathrm{~h}$. The grown colonies were calculated colony forming unit (CFU) per $\mathrm{ml}$. The plates containing more than $10 \mathrm{CFU} / \mathrm{ml}$ were selected as a significant growth, then gram stain for initial identification ${ }^{15}$. All grown colonies from primary cultures were subcultured onto Nutrient agar (LAB, UK) plates for the following confirm assays.

The confirm diagnosis for bacterial isolates was accomplished by analytical profile index (API) system (API 20E, API 20 STREP and API STAPH) add to motility, catalase, coagulase and oxidase tests described by Cheesbrough ${ }^{12}$.

\section{Antibiotic susceptibility testing}

Antimicrobial susceptibility patterns for bacterial isolates were performed by the standard disc diffusion method employing Muller-Hinton (LAB, UK) plates based on the guidelines of Clinical Laboratory Standards Institute ${ }^{16}$ using the following antibiotics disc: Amikacin (AK) $30 \mu \mathrm{g}$, Ampiclox (APX) 30 $\mu \mathrm{g}$, Ceftriaxone (CTR) $30 \mu \mathrm{g}$, Ciprofloxacin (CIP) 30 $\mu$ g, Co-trimoxazole (SXT) $25 \mu \mathrm{g}$, Gentamicin (CN) $10 \mu \mathrm{g}$, Imipenem (IMP) $10 \mu \mathrm{g}$, Nitrofurantoin (F) 300 $\mu$ g, Tetracycline (TE) $30 \mu \mathrm{g}$ (Titan, Biotech., India) and Cefexime (CFX) $5 \mu \mathrm{g}$ (Oxoid, UK). The inhibition zones of bacterial isolates for antibiotics were measured in $\mathrm{mm}$ by 
applying ordinary ruler.

\section{Statistical analysis}

Statistical analysis was achieved with the Chi-square test by Statistical Package for Social Sciences (SPSS) version 18. P-value less than 0.05 was considered as statistically significant and $P$-value less than 0.01 considered as highly significant.

\section{RESULTS}

\section{Growth and Gram's staining}

Out of 150 urine samples examined in this study, only $106(70.6 \%)$ samples yielded growth with a significant difference $(P \leq 0.01)$. Axenic culture was appeared in $88(83 \%)$ samples than mixed growth at $\mathrm{P} \leq 0.01$, as in Table 1 . Gramnegative bacteria were 85 (70.2\%), while Grampositive were $36(29.8 \%)$ at $\mathrm{P} \leq 0.01$ as in Table 2 .

Table 1. Growth of uropathogens isolated from urine samples in adult diabetic Patients

\section{Microbial Culture Number (\%)}

\begin{tabular}{lc}
\hline Axenic growth & $88(83)^{*}$ \\
Mixed growth & $18(17)$ \\
Total growth & $106(70.6)$ \\
No growth & $44(29.4)$ \\
Total samples & $150(100)$
\end{tabular}

$*: \mathrm{P} \leq 0.01$.

Table 2. Gram-staining of microbial isolates from urine samples in adult diabetic patients

\begin{tabular}{lc}
\hline Gram's Staining & Number (\%) \\
\hline Gram- Positive & $36(29.8)$ \\
Gram- Negative & $85(70.2)^{*}$ \\
Total isolates & $121(100)$ \\
\hline
\end{tabular}

$*: \mathrm{P} \leq 0.01$

\section{Prevalence of UTIs in diabetic patients according to some factors}

A total of 150 urine samples enrolled in this study, $84(56 \%)$ were of females and 66(44\%) were of males. Out of 106 positive cultures, the prevalence of UTIs was high in females 69 (65\%) than males with a significant difference at $\mathrm{P} \leq 0.01$. Furthermore, UTIs were more incidence in patients without antibiotics use and period of diabetes $5-10$ years ( $82 \%$ and $64 \%$, respectively), while it was $56.6 \%$ in age group $35-49$ years without signification, as in Table 3.

A total of 121 microbial isolates were obtained, Escherichia coli was the most common causative agent of UTIs with 64 isolates, followed by Klebsiella pneumonia, and Enterococcus faecalis (11 and 8, respectively). Streptococcus agalactiae and Klebsiella aerugenes were 5 for each. Moreover, Klebsiella oxytoca, Pseudomonas aeruginosa, Staphylococcus haemolyticus and Candida albicans were 3 for each. Nevertheless, the frequency of Proteus mirablis, Staphylococcus aureus, Streptococcus pyogenes, Serratia marcessens, Staphylococcus epidermidis and Staphylococcus warnerri was 2 for each, while Acinetobacter baumani and Bacillus subtilis were 1 for each.

\section{Antimicrobial susceptibility pattern}

Antibiotic susceptibility test for urinary bacterial isolates ${ }^{118}$ showed highly sensitive to imipenem (78.8\%) with significance differences at $\mathrm{P} \leq 0.01$, and Amikacin (61.9\%) at $\mathrm{P} \leq 0.05$. Furthermore, they were $56.5 \%, 50 \%$ and $44.9 \%$ for cefexime, ciprofloxacin and gentamicin respectively, but without signification. Moreover, they were low sensitivity to ceftriaxone, tetracycline and Co-trimaxazole (36.9\%, 29.7\% and $26.3 \%$, respectively). On the other hand, they were a highly resistance to ampiclox and nitrofurantoin (98.3\% and $87.3 \%$, respectively) at $\mathrm{P} \leq 0.01$, as in

Table 3. Prevalence of UTIs in diabetic patients according to some factors

\begin{tabular}{lcccccccccc}
\hline $\begin{array}{l}\text { Total } \\
* n(\%)\end{array}$ & $\begin{array}{c}\text { Sex } \\
\mathrm{n}(\%)\end{array}$ & \multicolumn{2}{c}{$\begin{array}{c}\text { Age Group } \\
\text { (year)n (\%) }\end{array}$} & \multicolumn{2}{c}{$\begin{array}{c}\text { Diabetes period } \\
\text { (year) } \mathrm{n}(\%)\end{array}$} & $\begin{array}{c}\text { Antibiotics } \\
\text { use } \mathrm{n}(\%)\end{array}$ \\
\hline 106 & Male & Female & $20-34$ & $35-49$ & $50-64$ & $<5$ & $5-10$ & $>10$ & Yes & No \\
$(100)$ & $37(35)$ & $69(65)^{* *}$ & $15(14.2)$ & $60(56.6)$ & $31(29.2$ & $25(23.6)$ & $68(64.1)^{* *}$ & $13(12.3)$ & $19(16)$ & $87(82)^{* *}$
\end{tabular}

\footnotetext{
$* \mathrm{n}$ : Number of the patients with positive culture $\quad * *: \mathrm{P} \leq 0.01$.

Frequency of uropathogens in diabetic patients
} 
Table 4. E. coli (64) appeared sensitive to imipenem and amikacin (89\% and $76.6 \%$, respectively) at $\mathrm{P} \leq$ 0.01 . K. pneumoniae ${ }^{11}$ was sensitive to amikacin $(72.7 \%)$ at $P \leq 0.01$, followed by imipenem, cefexime and ciprofloxacin (54.5\%, for each), but without signification. $K$. aerugenes ${ }^{5}$ was sensitive to imipenem (80\%) at $P \leq 0.01$, while it was $60 \%$ for amikacin, ciprofloxacin, gentamicin and ceftrixone at $\mathrm{P} \leq 0.05$. S. agalactiae $e^{5}$ was sensitive to imipenem (100\%), amikacin and ciprofloxacin (80\%, for each) at $\mathrm{P} \leq 0.01$, followed by cefixime, gentamicin and tetracycline (60\%, for each) at $\mathrm{P} \leq 0.05 . K$. oxytoca ${ }^{3}$ was sensitive to imipenem, amikacin, cefexime, and ceftriaxone (66.7\% for each) at $P \leq 0.01$. $S$. haemolyticus ${ }^{3}$ was sensitive to imipenem (100\%), cefixime and ciprofloxacin (66.7\%, for each) at $\mathrm{P} \leq 0.01$. S.pyogenes and S. warnerii (2, for each) were sensitive to imipenem and cefexime (100\%, for each). Serratia marssecens ${ }^{2}$ was sensitive to cefexime and ciprofloxacin (100\%, for each). $S$. epidermidis ${ }^{2}$ was sensitive to imipenem (100\%). Finally, B. subtilis ${ }^{1}$ was sensitive to imipenem,

Table 4. Antibiotic sensitivity profile of bacterial species isolated from adult diabetic patients with UTI

\begin{tabular}{|c|c|c|c|c|c|c|c|c|c|c|c|}
\hline \multirow[b]{2}{*}{$\begin{array}{l}\text { Bacterial } \\
\text { species }\end{array}$} & \multicolumn{10}{|c|}{ Antibiotic sensitivity $\mathrm{n}(\%)$} & \multirow[b]{2}{*}{ APX } \\
\hline & $* n$ & IMP & AK & CFX & $\mathrm{CN}$ & CIP & CTR & TE & SXT & $\mathrm{F}$ & \\
\hline Escherichia coli & 64 & $57(89)$ & $49(76.6)$ & $35(54.7)$ & $37(57.8)$ & $34(53.1)$ & $27(42.2)$ & $21(32.8)$ & $25(39)$ & $9(14)$ & $0(0)$ \\
\hline $\begin{array}{l}\text { Klebsiella } \\
\text { pneumoniae }\end{array}$ & 11 & $6(54.5)$ & $8(72.7)$ & $6(54.5)$ & $3(27.2)$ & $6(54.5)$ & $4(36.3)$ & $2(18.2)$ & $3(27.2)$ & $3(27.2)$ & $0(0)$ \\
\hline $\begin{array}{l}\text { Enterococcus } \\
\text { faecalis }\end{array}$ & 8 & $4(50)$ & $3(37.5)$ & $3(37.5)$ & $2(25)$ & $3(37.5)$ & $3(37.5)$ & $2(25)$ & $0(0)$ & $0(0)$ & $0(0)$ \\
\hline $\begin{array}{l}\text { Klebsiella } \\
\text { aerugenes }\end{array}$ & 5 & $4(80)$ & $3(60)$ & $3(60)$ & $3(60)$ & $3(60)$ & $3(60)$ & $2(40)$ & $1(20)$ & $1(20)$ & $0(0)$ \\
\hline $\begin{array}{l}\text { Streptococcus } \\
\text { agalactiae }\end{array}$ & 5 & $5(100)$ & $4(80)$ & $3(60)$ & $3(60)$ & $4(80)$ & $2(40)$ & $3(60)$ & $1(20)$ & $0(0)$ & $0(0)$ \\
\hline $\begin{array}{l}\text { Klebsiella } \\
\text { oxytoca }\end{array}$ & 3 & $2(66.7)$ & $2(66.7)$ & $2(66.7)$ & $1(33.3)$ & $1(33.3)$ & $2(66.7)$ & $1(33.3)$ & $0(0)$ & $0(0)$ & $2(40)$ \\
\hline $\begin{array}{l}\text { Pseudomonas } \\
\text { aeruginosa }\end{array}$ & 3 & $1(33.3)$ & $0(0)$ & $1(33.3)$ & $0(0)$ & $0(0)$ & $0(0)$ & $0(0)$ & $0(0)$ & $0(0)$ & $0(0)$ \\
\hline $\begin{array}{l}\text { Staphylococcus } \\
\text { haemolyticus }\end{array}$ & 3 & $3(100)$ & $1(33.3)$ & $2(66.7)$ & $1(33.3)$ & $2(66.7)$ & $0(0)$ & $0(0)$ & $0(0)$ & $0(0)$ & $0(0)$ \\
\hline Proteus mirablis & 2 & $1(50)$ & $0(0)$ & $1(50)$ & $0(0)$ & $0(0)$ & $0(0)$ & $0(0)$ & $0(0)$ & $0(0)$ & $0(0)$ \\
\hline $\begin{array}{l}\text { Staphylococcus } \\
\text { aureus }\end{array}$ & 2 & $1(50)$ & $0(0)$ & $1(50)$ & $0(0)$ & $0(0)$ & $0(0)$ & $0(0)$ & $0(0)$ & $0(0)$ & $0(0)$ \\
\hline $\begin{array}{l}\text { Streptococcus } \\
\text { pyogenes }\end{array}$ & 2 & $2(100)$ & $0(0)$ & $2(100$ & $1(50)$ & $1(50)$ & $0(0)$ & $0(0)$ & $0(0)$ & $0(0)$ & $0(0)$ \\
\hline $\begin{array}{l}\text { Staphylococcus } \\
\text { epidermidis }\end{array}$ & 2 & $2(100)$ & $0(0)$ & $1(50)$ & $0(0)$ & $1(50)$ & $0(0)$ & $1(50)$ & $0(0)$ & $0(0)$ & $0(0)$ \\
\hline $\begin{array}{l}\text { Staphylococcus } \\
\text { warnerii }\end{array}$ & 2 & $2(100)$ & $0(0)$ & $2(100)$ & $0(0)$ & $1(50)$ & $0(0)$ & $1(50)$ & $0(0)$ & $1(50)$ & $0(0)$ \\
\hline $\begin{array}{l}\text { Serratia } \\
\text { marssecens }\end{array}$ & 2 & $1(50)$ & $1(50)$ & $2(100)$ & $1(50)$ & $2(100)$ & $1(50)$ & $1(50)$ & $1(50)$ & $1(50)$ & $0(0)$ \\
\hline $\begin{array}{l}\text { Acinetobacter } \\
\text { baumanii }\end{array}$ & 1 & $1(100)$ & $1(100)$ & $0(0)$ & $0(0)$ & $0(0)$ & $0(0)$ & $0(0)$ & $0(0)$ & $0(0)$ & $0(0)$ \\
\hline Bacillus subtilis & 1 & $1(100)$ & $1(100)$ & $1(100)$ & $1(100)$ & $1(100)$ & $1(100)$ & $1(100)$ & $0(0)$ & $0(0)$ & $0(0)$ \\
\hline Total & 118 & $\begin{array}{c}93 \\
(78.8)^{* *}\end{array}$ & $\begin{array}{c}73 \\
(61.9)^{* * *}\end{array}$ & $\begin{array}{c}65 \\
(56.5)\end{array}$ & $\begin{array}{c}53 \\
(44.9)\end{array}$ & $\begin{array}{c}59 \\
(50)\end{array}$ & $\begin{array}{c}43 \\
(36.4)\end{array}$ & $\begin{array}{c}35 \\
(29.7)\end{array}$ & $\begin{array}{c}31 \\
(26.3)\end{array}$ & $\begin{array}{c}15 \\
(12.7)\end{array}$ & $\begin{array}{c}2 \\
(1.7)\end{array}$ \\
\hline
\end{tabular}

${ }^{*}$ n: Number of isolates, ${ }^{* *}: \mathrm{P} \leq 0.01, * * *: \mathrm{P} \leq 0.05$.

IMP: Imipenem, AK: Amikacin, CFX: Cefixime, CN: Gentamicin, CIP: Ciprofloxacin, CTR: Ceftriaxone, TE: Tetracycline, SXT: Cotrimoxazole, F: Nitrofurantoin, APX: Ampiclox 
amikacin, cefexime, ciprofloxacin, gentamicin, ceftriaxone and tetracycline (100\%, for each). While $A$. baumanii ${ }^{1}$ was $100 \%$ sensitive for imipenem and amikacin.

\section{DISCUSSION}

The present study showed that axenic culture was $83 \%$ versus to mixed growth, this result in agreement with $\mathrm{Abd} \mathrm{Al}$ Abbas and Jasim ${ }^{17}$ founding $82 \%$ of samples gave axenic growth. Axenic refer to pure colonies from the primary culture, as in Table 1. Furthermore, this study showed that a large proportion of uropathogens were gram-negative comparing to gram-positive isolates as in Table 2. This result is consistent with previous studies ${ }^{10,18,19}$.

Table (3) shows the prevalence of UTI according to some factors. The results revealed a high prevalence of UTI in females (65\%), in agreement with other previously reported studies $^{9-11,19}$. Females are more prone to have UTI than males because the urethra is shorter and closer to the anus adding to a sexual intercourse ${ }^{20}$. Nevertheless, this study showed that the occurrence of UTI in diabetes was more frequently in the age group (35-49 years), followed by the age group(50-64 years) in agreement with study done by Adeyeba et al. ${ }^{21}$. Generally, engagement in sexual activity and increasing age of diabetics make them vulnerable to urinary tract infection ${ }^{22}$. Moreover, UTI occurrence was more frequent in patients without antibiotics use and diabetic period (5-10 years). Indiscriminate and uncontrolled use of antibiotics for long period with chronic glucosuria encouraging the microbial growth and thereby increase the risk of UTIs ${ }^{23,24}$.

The present study showed that $E$. coli was the most common bacteria with 64 isolates (52.9\%), followed by Klebsiella spp. 19(15.7\%) isolates then $E$. faecalis $8(6.6 \%)$ isolates and S. agalactiae $5(4.1 \%)$ isolates. Several studies reported that E. coli and Klebsiella spp. were the most frequent uropathogens in diabetic patients, while the other species were different ${ }^{10,18,19,25}$. Relatively, UTIs occur when gastro-intestinal bacteria can be entering to the urethra and then colonization, once these bacteria gain access to the urinary bladder they may multiply and transmitting up through ureters to kidneys ${ }^{14}$. $E$. coli is normally habitat in the intestinal tract, it is most predominant bacterium causing UTI in both diabetic and non- diabetic patients ${ }^{11,25,26}$. E. coli have numerous virulence factors which enable to colonize the urethra such as P-fimbria to bind the epithelium, other factors contribute in its pathogenicity like $\alpha$ and $\beta$-hemolysins, colicins and cytotoxic necrotizing factor ${ }^{27}$. Klebsiella spp. are opportunistic pathogens and they are the etiological agents for urinary tract infection in both community-acquired and hospital- acquired infections. Capsule production, siderophore activity and biofilm formation are an important virulence factors in pathogenesis of Klebsiella ${ }^{28}$. Enterococcus faecalis is also opportunistic bacterium and it's the causative agent for UTI in the general population ${ }^{26}$. This bacterium has many virulence factors playing an important role in its pathogenicity such as aggregation substance, Enterococal surface protein and hemolysins ${ }^{29}$. On the other hand, $S$. agalactiae has been isolated from patient with poorly glucosuria ${ }^{10}$. Although, the bacterium form a part of urogenital flora, but became opportunistic, particularly in patient with poor immunity.

Table (4) showed that the uropathogenic bacteria were highly sensitive to imipenem (78.8\%), followed by Amikacin (61.9\%). These results are consistent with other previous studies ${ }^{18,19,25}$. In contrast, all bacterial species appeared a complete resistance to ampiclox (100\%) with the exception of S. agalactiae (60\%). This is due to the acquisition of mec $A$ gene by plasmid transferring ${ }^{30,31}$. On the other hand, many bacterial species appeared resistant to three or more antibiotics which may be due to plasmid carrying drug resistant genes, a biofilm formation inside the urinary bladder increases the chance of multi-drug resistance bacteria to colonize the urinary tract and thus to infection $^{32,33}$. Furthermore, MDR efflux - system contributes to the emergence of multi- drug resistance strains, especially in gram - negative bacteria $^{34,35}$. Additionally, the exposure of bacterial pathogens to high concentration of antibiotics for long times creates severe selection pressure leading to emergence of resistance ${ }^{36}$.

\section{CONCLUSION}

The prevalence of UTIs was higher in females comparing of males, and the age group (35-49) years in adult diabetic patients. Escherichia 
coli was identified as the most common causative agent of UTIs in diabetes in Misan province. Although, the high rate of multi - drug resistance among bacterial isolates, but imipenem is a very effective antibiotic.

\section{ACKNOWLEDGMENTS}

None

\section{FUNDING}

None

\section{DATA AVAILABILITY}

All datasets generated or analyzed during this study are included in the manuscript.

\section{ETHICS STATEMENT}

This article does not contain any studies with human participants or animals performed by any of the authors.

\section{REFERENCES}

1. Kunin C.M. Chemoprophylaxis and suppressive therapy in the management of urinary tract infections. $J$. Antimicrob. Chemoth.,1994; 33(suppl-A): 51-62.

2. Gupta K., Sahm D.F. Mayfield D. \& Stamm W.E. Antimicrobial resistance among uropathogens that cause community-acquired urinary tract infections in women: A nationwide analysis. Clin. infect.dis.,2001; 33(1): 89-94.

3. American Diabetes Association: Diagnosis and classification of diabetes Mellitus. Diabetes Care2014; 38: S81-S90.

4. Nitzan O., Elias M., Chazan B. \& Saliba W. Urinary tract infections in patients with type 2 diabetes mellitus: Review of prevalence, diagnosis, and management. Diab., metabol. synd. and obesit.: targets and therap., 2015; 8: 129-136.

5. Saleem M. and Daniel B. Prevalence of Urinary Tract Infection among Patients with Diabetes in Bangalore City. Int. J. Emerg. Sci 2011; 2(1): 133-142.

6. Bonadio M, Costarelli S, Morelli G \& Tartaglia T. The influence of diabetes mellitus on the spectrum of uropathogens and the antimicrobial resistance in elderly adult patients with urinary tract infection. $B M C$ infec. dis., 2006; 6(54): 1-7.

7. Geerlings S.E., Stolk R.P., Camps M.J., Netten P.M., Collet T.J., Hoepelman A.I. \& Group, D.W. B. U. S. Risk factors for symptomatic urinary tract infection in women with diabetes. Diabetes Care, 2000; 12(23): 1737-1741.

8. Geerlings S.E., Stolk R.P., Camps M.J., Netten P.M., Hoekstra J.B., Bouter K.P., et al.. Asymptomatic bacteriuria may be considered a complication in women with diabetes. Diabetes mellitus women asymptomatic bacteriuria utrecht study group. Diabetes care, 2000; 6(23): 744-749.
9. Rangari A.A., Sharma S., Tyagi N., Singh P., Singh G. \& Thakur R. Antibiotic susceptibility pattern of bacterial uropathogens isolated from patients at a tertiary care hospital in western uttar pradesh of india. J. Curr. Microbiol. Appl. Sci, 2015; 10(4): 646-657.

10. Tektook N.K., Al-Lehibi K.I. \& Al-Husseinei R.K. Prevalence some pathogenic bacteria causing uti in diabetic patients in/specialized center for endocrinology and diabetes of baghdad city-iraq. Med. J. Babylon, 2017; 14(2): 260-266.

11. Alhamdany M.H.A. 2018. Antibiotic susceptibility of bacteria isolated from patients with diabetes mellitus and recurrent urinary tract infections in babylon province, iraq. Med. J. Babyl., 2018; 15(1):63-68.

12. Cheesbrough M. District Laboratory Practice in Tropical Countries; p.434. 2ndEd. Cambridge University Press, 2006.

13. Weber J.T. \& Courvalin P. An emptying quiver: Antimicrobial drugs and resistance. Emerg. Infect. Dis., 2005; 11(6): 791-793.

14. Tille P.M. Bailey and Scott's: Diagnostic Microbiology, p 1001. 13thEd. Mosby Inc., an affiliate of Elsevier Inc., 2014.

15. Sham D, Weissfeld A \& Forbes B. Bailey \& Scott's diagnostic microbiology. pp60-80.12th Ed. Mosby Inc., an affiliate of Elsevier Inc, 2014.

16. CLSI editor. Clinical and Laboratory Standards Insitute. Performance Standards for Anti-microbial Susceptebility Testing; 2012: Twenty-second Informational Supplement M100-S22. Wayne, PA, USA.

17. Abd Al-Abbas M.J. and Jasim N.A. Molecular study of urinary tract infection bacteria and their relationship to the present of Oxalobacter-formigenes in stool of kidney stone patients.Am. Sci. Res. J. Engine. Tech. Sci. 2016; 1(26): 230-249.

18. Yadav K \& Prakash S. Antimicrobial resistance pattern of uropathogens causing urinary tract infection (uti) among diabetics. Biomed. Res. Intern., 2016; 1: 07-15.

19. Almazini M. Incidence and sensitivity of bacterial uropathogens among diabetic patients. Eur. J. Exper. Biol., 2016; 6(3): 8-12.

20. Kunin C.M. Urinary tract infections in females. Clin. Infect. Dis. 1994; 1(18): 1-12.

21. Adeyeba O.A., Adesiji Y.O., Omosigho P.O. Bacterial Urinary Tract Infections in Patients with Diabetes Mellitus Int. Trop. J. Med. 2007; 3(2): 89-92.

22. Kumar Jha P., Baral, R. \& Khanal B. Prevalence of uropathogens in diabetic patients and their susceptibility pattern at a tertiary care center in nepal-a retrospective study. Int. J. Bio. Lab. Sci., 2014; 3(2): 29-34.

23. F nfst ck R., Nicolle L.E., Hanefeld M. \& Naber K.G. Urinary tract infection in patients with diabetes mellitus. Clin. nephro., 2012; 77(1): 40-48.

24. Wang M.C., Tseng C.C., Wu A.B., Lin W.H., Teng C.H., Yan J. \& Wu J.J. Bacterial characteristics and glycemic control in diabetic patients with escherichia coli urinary tract infection. J. Microbiol., Immuno.Infect., 2013; 46(1): 24-29.

25. Rashmi B. \& Venkatesha D. Antibiogram of urinary pathogens in patients with diabetes mellitusexperience from a tertiary care hospital. Int. J. Curr. 
Microbiol. App. Sci, 2017; 6: 4830-4837.

26. Acharya D., Bogati B., Shrestha G. \& Gyawali P. Diabetes mellitus and urinary tract infection: Spectrum of uropathogens and their antibiotic sensitivity. J. Manmohan Memorial Inst. of Health Sci., 2015; 1(4): 24-28.

27. Kausar Y., Chunchanur S.K., Nadagir S.D., Halesh L. \& Chandrasekhar M. Virulence factors, serotypes and antimicrobial suspectibility pattern of Escherichia coli in urinary tract infections. Al Ameen. J. Med. Sci., 2009; 2(1): 47-51.

28. Clegg S. \& Murphy C.N. Epidemiology and virulence of klebsiella pneumoniae. Microbio. spect., 2016; 4(1): 1-17.

29. Upadhyaya P.G., Ravikumar K. \& Umapathy B. Review of virulence factors of Enterococcus: An emerging nosocomial pathogen. Indian j. med. microbiol., 2009; 27(4): 301.

30. Ito T., Katayama Y., Asada K., Mori N., Tsutsumimoto K., Tiensasitorn C. \& Hiramatsu K. Structural comparison of three types of staphylococcal cassette chromosome mec integrated in the chromosome in methicillinresistant staphylococcus aureus. Antimicrob. agents and chemo., 2001; 45(5): 1323-1336.

31. Abd Al-Abbas M.J. Antimicrobial susceptibility of enterococcus faecalis and a novel plano-microbium isolate of bacterimia. Int. J.Med. and Med. Sci., 2012; 4(2): 19-27.

32. Stamm W.E. Urinary tract infections, pyelonephritis, and prostatitis. Harrison's Principles of In. Med. 17th ed New York, NY: McGraw-Hill, 2008; 1820-1827.

33. Shalini J.M., Rashid M. \& Joshi H. Study of antibiotic sensitivity pattern in urinary tract infection at a tertiary hospital. NJIRM, 2011; 2(3): 43-46.

34. Sulavik M.C., Houseweart C., Cramer C., Jiwani N, Murgolo N., Greene J, et al.. Antibiotic susceptibility profiles ofEscherichia coli strains lacking multidrug efflux pump genes. Antimicrob. agents and chemother., 2001; 45(4): 1126-1136.

35. Hirsch E.B. \& Tam V.H. Impact of multidrug-resistant Pseudomonas aeruginosa infection on patient outcomes. Expert rev. pharma.\& outcomes res., 2010; 10(4): 441-451.

36. Brisson-Noel A., Arthur M. \& Courvalin P. Evidence for natural gene transfer from gram-positive cocci to Escherichia coli. J. bacterio., 1988; 170(4): 1739-1745. 